Journal of Applied Biosciences 158: 16282 - 16288

ISSN 1997-5902

\title{
Safety of the butanol fraction of Cocos nucifera roots aqueous extract in vivo.
}

\author{
Tchogou AP1, 2, Sènou M1, 2*, Lokonon JE1, Agbogba F1, 3, Medoatinsa SE1, 4, Abissi GY1, Loko F2 \\ ${ }^{1}$ Experimental and Clinic Biology Laboratory, National School of Applied Biosciences and Biotechnology, National \\ University of Sciences, Technologies, Engineering and Mathematics (UNSTIM), Dassa-Zoumé, R. Benin. \\ 2 Research Laboratory in Applied Biology, Polytechnic School of Abomey-Calavi, University of Abomey-Calavi, \\ Cotonou, R. Benin. \\ ${ }^{3}$ Laboratory of Biomembrane and Cell Signaling, Faculty of Sciences and Techniques, University of Abomey-Calavi, \\ R Benin. \\ ${ }^{4}$ Laboratory of Study and Research in Applied Chemistry, Polytechnic School of Abomey-Calavi, University of Abomey- \\ Calavi, R. Benin. \\ *Corresponding email senouxim@yahoo.fr; tel: 0022997265827
}

Original submitted in on $9^{\text {th }}$ December 2020. Published online at www.m.elewa.org/journals/ on $28^{\text {th }}$ February 2021 https://doi.org/10.35759/JABs.158.2

\begin{abstract}
Objective: Cocos nucifera (coconut tree) is a tropical plant whose roots were used in Benin to treat anaemia. These roots contain anthocyanins, which are isolated by butanol. This work aimed to test the safety of the butanolic fraction of this root extract.

Methodology and results: Acute oral toxicity (AOT) and subchronic (SCT) tests were performed by gavage Wistar rats with the fraction of the extract at a single dose of $2000 \mathrm{mg} / \mathrm{Kg}$ of weight for the AOT and of 200 $\mathrm{mg} / \mathrm{Kg} /$ Day for 28 days for SCT. At D0 and on D14 for the AOT and on D28 for the SCT, the rats were weighed and sampled for assay of transaminases AST and ALT, uraemia, creatinine, blood leukocyte counts and liver, kidneys and spleen histology. These analyses did not show any abnormalities. The butanol fraction of the aqueous extract of Cocos nucifera roots did not show acute or sub-chronic oral toxicity. The physical balance assessed by the behaviour and weight of rats was normal. Liver function tests performed by transaminases AST and ALT improved. Renal balance conducted by uraemia and creatinine was normal. The immune status determined by the number of blood leukocytes was normal. These functional observations were confirmed by the histology of the liver, kidneys and spleen, which did not show any morphological atypia of these organs.

Conclusion and application of results: The lack of toxicity at the acute or subchronic stage may be related to anthocyanins contained therein and some of which were known to be non-toxic. This result opened up great prospects for testing various biological properties, in particular the hematopoietic activity of this butanolic fraction of Cocos nucifera root extract which will be used as an improved traditional medicine.
\end{abstract}

Key words: Cocos nucifera, butanol, safety. 


\section{RÉSUMÉ}

Objectif : Cocos nucifera est une plante tropicale dont les racines sont utilisées au Bénin pour soigner l'anémie. Ces racines contiennent les anthocyanes qui sont isolés par le butanol. Ce travail se propose de tester l'innocuité de la fraction butanolique de cet extrait de racines.

Méthodologie et résultats : Les Tests de toxicité orale aigüe (TOA) et subchronique (TSC) ont été effectués par gavage de rats Wistar avec la fraction d'extrait à la dose unique de $2000 \mathrm{mg} / \mathrm{Kg}$ de poids pour la TOA et de $200 \mathrm{mg} / \mathrm{Kg} / \mathrm{Jour}$ pendant 28 jours pour la TSC. A J0, puis à J14 pour le TAO et à J28 pour le TSC, les rats ont été pesés puis prélevés pour le dosage des transaminases ASAT et ALAT, l'urémie, la créatininémie, la numération des leucocytes sanguins et l'histologie du foie, des reins et de la rate. Ces analyses n'ont pas montré d'anomalies. La fraction butanolique de l'extrait aqueux de racines de Cocos nucifera n'a pas révélé de toxicité orale aiguë ou sub-chronique. Le bilan physique évalué par le comportement et le poids des rats est normal. Le bilan hépatique effectué par les transaminases ASAT et ALAT est amélioré. Le bilan rénal réalisé par l'urémie et la créatininémie est normal. Le bilan immunitaire déterminé par le nombre de leucocytes sanguins est normal. Ces observations fonctionnelles sont confirmées par l'histologie du foie, des reins et de la rate qui n'a pas montré d'atypies morphologiques de ces organes.

Conclusion et application des résultats :L'absence de toxicité orale à l'état aigu ou subchronique serait liée aux anthocyanes qui y sont contenus et dont certains sont connus comme étant non toxiques. Ce résultat ouvre de belles perspectives pour tester diverses propriétés biologiques, notamment l'activité hématopoïétique de cette fraction butanolique de l'extrait de racines de Cocos nucifera qui sera utilisé comme medicament tradiotionnel amélioré.

Mots clés : Cocos nucifera, butanol, innocuité.

\section{INTRODUCTION}

Various populations used medicinal plants to solve health problems around the world. About $80 \%$ of people living in rural areas are affected by this practice (Schmincke, 2003; Yakubu et al., 2009 Pingali et al., 2015 ;). Various scientific studies show the therapeutic efficacy of these traditional remedies (Gbénou et al., 2006 ; Diallo et al., 2008, Sènou et al., 2016). These plants contained many active substances that cure or relieve ailments (Okigbo et al., 2008). However, few questions are asked about the toxicity of plants used in traditional medicine (Oduola et al., 2007). Various studies show toxic effects of several plants used as therapeutic remedies. This was the case, for example, with products made from leaves of Larrea tridentata, used as an anticoagulant and for weight loss but which exhibited carcinogenic, hepatotoxic and nephrotoxic effects (Arteaga S, 2005). Nephrotoxic effects have also been associated with herbal medicines used in the treatment of diabetes (Mapanga and Musabayane, 2010). Aloe, made from leaves of Aloe vera and used as laxative revealed a genetic cytotoxicty (Verma A, 2012). It it therefore important to analyze the safety of medicinal plants before any use (Philomena G, 2011; Nasri H, 2013). Cocos nucifera Linn is a tropical coastal plant. Its roots were used in traditional medicine in Benin to treat anaemia (Harries et al, 1978 ; Tchogou et al, 2016). The phytochemical screening of the aqueous extract of these roots having revealed various families of phytochemicals, it would be interesting to see which of these families exert the hematopoietic activity (Tchogou et al., 2017). One of these identified families were the anthocyanins which were isolated by the extract fractionation with butanol (Manjusha et al., 2013 ; Koudoro et al., 2014). Before testing the hematopoietic activity of the butanolic fraction of Cocos nucifera roots aqueous extract, the present work first set out to test its safety in vivo in animal experiments. 


\section{MATERIALS AND METHODS}

Animal material: eight Wistar rats with average body weight of approximately $160 \mathrm{~g}$. They had free access to water and food and were acclimatized to the breeding conditions of the animal house of the research laboratory in applied biology of the Polytechnic of Abomey-Calavi of the University of Abomey-Calavi in Benin. The animal house was airy and well ventilated with a 12-hour daynight rhythm. The animals were kept in wire mesh cages equipped with drinkers and feeders. The food was in croquettes marketed by the company Vet service (Benin). The enclosure was regularly cleaned to ensure optimal development of the animals avoid infection. All the rules for animal welfare have been observed.

\section{Preparation of Plant Material:}

- Identification: Cocos nucifera roots were collected and in April 2015 in Abomey-Calavi in Benin. The collected samples were identified at the National Herbarium of Benin (HNB) at the University of Abomey Calavi. The samples were dried at moderate temperatures $\left(20-25^{\circ} \mathrm{C}\right)$, protected from moisture for four weeks. They were then crushed into powder and stored in suitable containers at room temperature.

- Preparation of the aqueous extract : Fifty $(50) \mathrm{g}$ of root powder of Cocos nucifera were boiled in $500 \mathrm{ml}$ of distilled water in a $1000 \mathrm{ml}$ flask for 30 minutes. After cooling, the mixture was filtered using the Bushner. This operation was repeated for six times for a total mass of $300 \mathrm{~g}$. The filtrate (the aqueous phase) obtained was recovered and stored in a refrigerator in a jar for liquidliquid extraction (first fractionation step).

- Fractionation of the extract: Liquid-liquid extraction consists in passing a substance from a solvent, from which it is often difficult to separate, to another (called extraction solvent), from which it will be easily isolable. This operation, usually carried out by stirring, is possible provided that the two solvents are very little or no miscible with one another. But extraction is never $100 \%$, there are always molecules of the compound to be extracted in the solvent in which it is less soluble. The Liquid-liquid was obtained by successive partitions with solvents of increasing polarity (hexane and butanol) according to the protocol of Koudoro et al. (2014). In a separatory funnel, the aqueous extract solution was added the appropriate volume of extraction solvent. After vigorous agitation, the mixture was allowed to settle. After decantation, the two phases were separated by collecting the lower phase (aqueous phase) in a flask and the upper phase (organic phase) in another. The aqueous phase was re-poured into the separating funnel before repeating the steps. After each extraction step, the organic phases were combined, which constituted the fraction in a jar. The liquid-liquid extracts obtained was then evaporated using a rotary evaporator at a temperature according to the solvents polarity. The extractant phase (Koudoro et al. 2014) was re-sealed and solidified in an oven at $40^{\circ} \mathrm{C}$. The dry residue obtained was reduced to powder and stored in a refrigerator in a brown flask. The yield of the fraction was calculated by the following formula :

$$
\mathrm{R}=\frac{\text { Mass of fraction }}{\text { Mass of powder }} \times 100
$$

Acute toxicity test: Acute toxicity test was carried out as recommended by the guideline 423 of the Organization for Economic Cooperation and Development for the testing of chemicals (OECD, 2002). The substance was tested in a sequential process in which three animals including multiparous females and no pregnant (OECD, 2002) aged 8 to 12 weeks are used at each stage. The absence of mortality or substancerelated manifestations in a one-step dose group would determine the next step. The initial dose was selected from the following four doses: 5, 50, 300 and $2000 \mathrm{mg} /$ $\mathrm{kg}$ body weight. $2000 \mathrm{mg}$ of Cocos nucifera butanol extract fraction $/ \mathrm{kg}$ body weight was administered by gavage to the animals. The animals were observed carefully during the four (4) hours and then daily for 14 days. They were weighed and blood was collected by orbital puncture at the start of the experiment and then after 14 days.

Sub-chronic toxicity tests : Five Wistar rats received the Cocos nucifera butanol extract fraction at $200 \mathrm{mg} / \mathrm{kg}$ body weight, daily for 28 consecutive days by gavage (Biswas et al., 2010). They were weighed and blood was collected by orbital puncture at the start of the experiment and then after 28 days.

Blood tests : Performed Blood tests were uremia and serum creatinine for renal function exploration. ASAT and ALAT transaminases were assayed for hepatic function. The blood leukocyte count aimed to analyze immune function.

Histology: At the end of the experiment, the animals were dissected. The liver, the kidney and the spleen were removed, fixed in formaldehyde solution, and embedded in paraffin. The specimens sections $(5 \mu \mathrm{m})$ were mounted on glass slides, deparaffinated, and hydrated. For histological analysis, sections were stained with hematoxylin and eosin (H\&E), following a 
standard protocol (Sènou et al, 2009). The pictures were taken at $400 \mathrm{X}$ magnification.

\section{RESULTS}

The butanol fraction of the aqueous extract of roots of Cocos nucifera did not exhibit acute toxicity: The acute oral toxicity was evaluated by measuring the weight of the rats, as the physical parameter. The blood
Statistical Analysis: The means were compared using Mann-Whitney test. The significance level was set at $5 \%$.

urea and creatinine for renal function tests, the transaminases AST and ALT for liver function and finally that the number of blood leukocytes for the immune check, was also done (Table 1).

Table 1 : Acute oral toxicity

\begin{tabular}{|l|l|l|l|l|}
\hline Parameters & Means at D0 & Means at D14 & Value & Difference \\
\hline Rat weight (g) & $160 \pm 7$ & $157 \pm 5$ & 0.5 & no significant \\
\hline Uremia (g/ / ) & $0.53 \pm 0.11$ & $0.61 \pm 0.15$ & 0.5 & no significant \\
\hline Creatinine (mg /L) & $9 \pm 4$ & $8 \pm 3$ & 0.3 & no significant \\
\hline Transaminase AST (IU / L) & $109 \pm 8$ & $103 \pm 11$ & 0.4 & no significant \\
\hline Transaminase ALT (IU / L) & $70 \pm 10$ & $57 \pm 8$ & 0.4 & no significant \\
\hline White Blood Cells (G/L) & $6.5 \pm 1.3$ & $7.5 \pm 1.1$ & 0.8 & no significant \\
\hline
\end{tabular}

The mean rat weight at D0 of $160 \pm 7 \mathrm{~g}$ did not significantly change at D14 in accordance with the general behavior of rats which did not also change. Uremia and serum creatinine respectively of $0.53 \pm 0.11$ $\mathrm{g} / \mathrm{L}$ and $9 \pm 4 \mathrm{mg} / \mathrm{L}$ on D0 did not significantly increase on D14, indicating no disturbance of renal function. The AST and ALT transaminases of $109 \pm 8 \mathrm{U} / \mathrm{L}$ and $70 \pm$ $10 \mathrm{U} / \mathrm{L}$ respectively on D0 experienced a slight nonsignificant decrease on D14, suggesting an absence of hepatic cytolysis. The mean number of blood leukocytes of $6.5 \pm 1.3 \mathrm{G} / \mathrm{L}$ on $\mathrm{D} 0$, did not significantly change on D14 indicating preservation of immune function.

The butanolic fraction of the aqueous extract of Cocos nucifera roots is not toxic in a subchronic state: The acute oral toxicity was evaluated by the same parameters measured for the acute toxicity, namely the weight of the rats, the uremia, the AST and ALT transaminases and finally that of the number of blood leukocytes (Table 2).

Table 2 : Subchronic toxicity

\begin{tabular}{|l|l|l|l|l|}
\hline Parameters & Means at D0 & Means at D28 & Pvalue & Difference \\
\hline Rat weight (g) & $153 \pm 11$ & $165 \pm 7$ & 0.5 & no significant \\
\hline Uremia (g/ / ) & $0.65 \pm 0.08$ & $0.61 \pm 0.09$ & 0.4 & no significant \\
\hline Creatinine (mg /L) & $8 \pm 2$ & $8 \pm 1$ & 0.8 & no significant \\
\hline Transaminase AST (IU / L) & $125 \pm 9$ & $118 \pm 11$ & 0.6 & no significant \\
\hline Transaminase ALT (IU / L) & $68 \pm 10$ & $61 \pm 15$ & 0.5 & no significant \\
\hline White Blood Cells (G/L) & $7.3 \pm 1.5$ & $8.0 \pm 1.1$ & 0.3 & no significant \\
\hline
\end{tabular}

The average rat weight at D0 of $153 \pm 11 \mathrm{~g}$ did not significantly change on D28 in accordance with the general behavior of rats which did not also change. Uremia and creatininemia, respectively $0.65 \pm 0.08 \mathrm{~g} / \mathrm{L}$ and $8 \pm 2 \mathrm{mg} / \mathrm{L}$ on D0 did not significantly increase on D28, indicating no disturbance of renal function. The AST and ALT transaminases of $125 \pm 9 \mathrm{U} / \mathrm{L}$ and $68 \pm$ $10 \mathrm{U} / \mathrm{L}$ respectively on D0 experienced a slight nonsignificant decrease on D28, suggesting an improvement in hepatic function. The mean number of blood leukocytes of $7.3 \pm 1.5 \mathrm{G} / \mathrm{L}$ on D0, did not significantly change on D14 indicating preservation of the immune function.

The butanol fraction of the aqueous extract of Cocos nucifera roots did not induce histological damage in the liver, kidneys and spleen in acute and subchronic state: In the acute oral toxicity test (Figure 1B) and sub-chronic (Figure 1C), the liver parenchyma displayed normal architecture as in controls (Figure 1A). Hepatocytes (arrow) with typical appearance were organized in cords around the central vein (V). The venous sinusoids $(S)$ were well placed between the cords. 
The renal parenchyma in acute oral toxicity tests (Figure $1 \mathrm{E})$ and subchronic (Figure 1F) was typical as in the control rats (Figure 1D). The renal glomeruli $(G)$, the proximal (PT) and distal (DT) tubules as well as the collecting ducts $(C D)$ were characteristic in appearance. The splenic parenchyma with acute oral toxicity test
(Figure $1 \mathrm{H}$ ) and sub-chronic (Figure 1l) was typical as in the control rats (Figure 1G). The periarteriolar (AS) sleeves around the central arteries (CA) and germinal centers (GC) of the white pulp displayed a normal, unactivated appearance. The sinusoids (S) and Billroth's cords $(\mathrm{BC})$ of the red pulp were also characteristic.
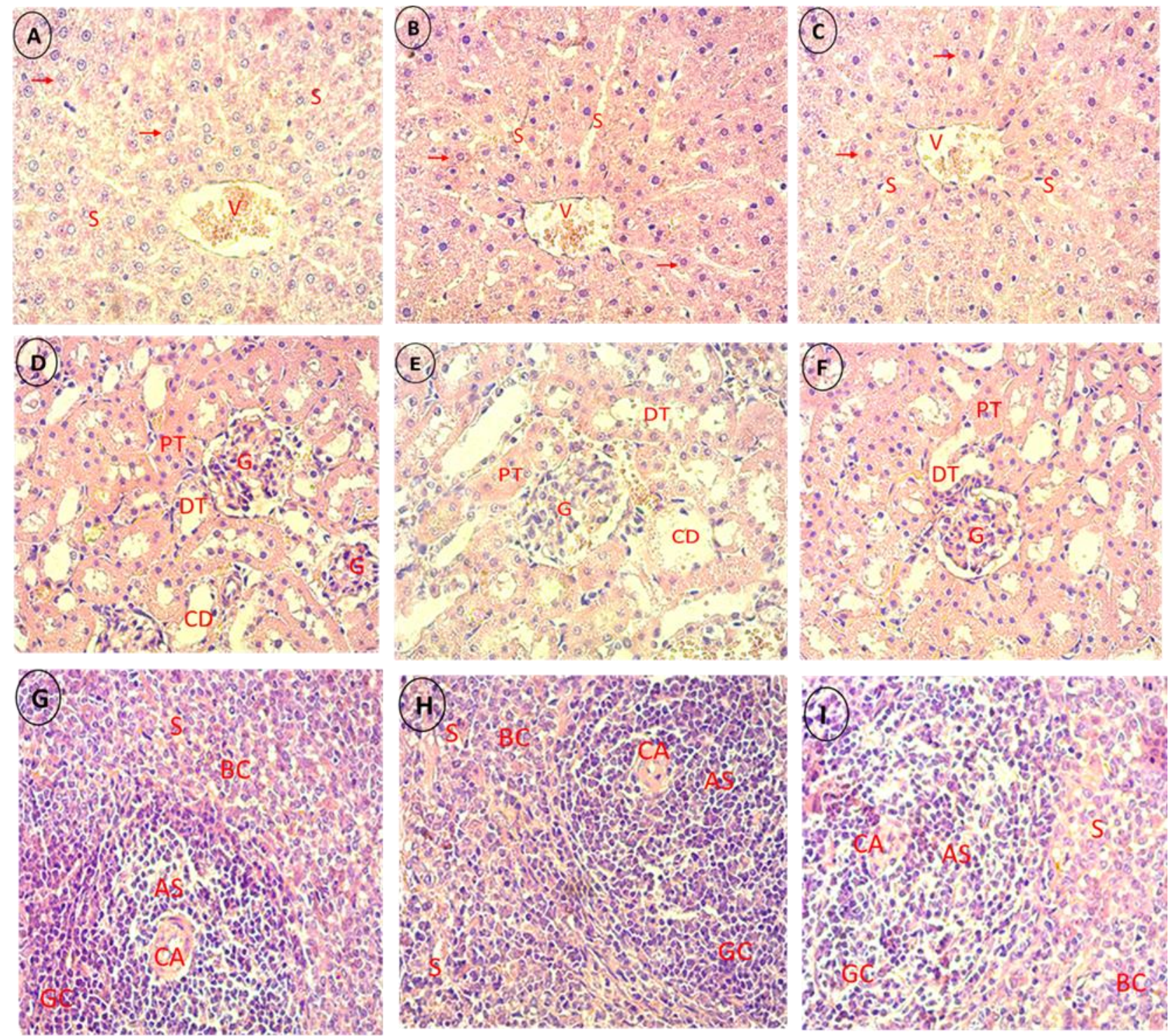

Figure 1 : hepatic $(A, B$ and $C)$, renal $(C, D$ and $E)$ and splenic $(G, H$ and $I)$ parenchyma of rats in acute and subchronic oral toxicity tests.

Magnification : 400x

\section{DISCUSSION}

The roots of Cocos nucifera $L$ were used to treat anemia and contains anthocyanins also found in other plants with hematopoietic properties (Sènou et al., 2016 ; Tchogou et al., 2016). This study tested the safety of the butanol fraction isolating anthocyanins majority
(Manjusha et al, 2013 ; Koudoro et al, 2014), as a prelude to seeking their hematopoietic potential effectiveness. For this purpose, acute and subchronic oral toxicity tests of the butanol fraction of the aqueous extract of the roots of Cocos nucifera were carried out on 
Wistar rats following the recommendations of the OECD (2000). The ratsweight, liver, kidney, immune function and histology of these organs were analyzed. In the acute and subchronic oral toxicity tests, the weight of the rats and their behavior were not altered. This observation was consistent with those of the crude extract of the root or its ethyl acetate fraction previously studied (Tchogou et al, 2017, Sènou et al, 2017). The same observation was also made with liquid green shell coconut or its butanoic extract (Costa et al, 2011). In acute and subchronic oral toxicity tests, hepatic status determined by AST and ALT transminases was improved, indicating an absence of cytolysis and protection of hepatic function by the butanol fraction. This observation was consistent with that made on the water of Cocos nucifera which lowered AST and ALT transaminases in a model of carbon tetrachloride poisoning (Evans et al, 2001). The absence of hepatotoxicity was confirmed by histology which showed typical liver parenchyma. Renal function was not affected by acute and subchronic oral toxicity testing of the butanol fraction of the extract, as blood urea and serum creatinine were not increased. The absence of neprotoxicity was confirmed by histology which showed a typical appearance of the renal

\section{REFERENCES}

Arteaga S, Andrade-Cetto A, Cardenas R, 2005. Larrea tridentata (creosote bush), an abundant plant of Mexican and US-American deserts and its metabolite nordihydroguaiaretic acid. Journal of Ethnopharmacology 98: 231-239.

Biswas M, Kar B, Karan TK, Bhattacharya S, Kumar RBS, Ghosh AK, Haldar PK, 2010. Acute and sub-chronic toxicity study of Dregea volubilis fruit in mice. J Phytol. 2(8): 6-10.

Costa CTC, Bevilaqua CML, Nascimento DCS, NunesPinheiro DCS, da Rocha TA, CamurçaVasconcelos ALF, de Oliveira LMB, 2011. Toxicological activity evaluation of Cocos nuciferal in experimental models. Ciência Animal 21(1):35-44.

Diallo A, Gbeassor M, Vovor A, Eklu-Gadegbeku K, Aklikokou K, Agbonon A, 2008. Effect of Tectona grandis on phenylhydrazine induced anaemia in rats. Fitoterapia 79: 332-6.

Gbenou JD, Tossou R, Dansou P, Fossou M, Moudachirou M, 2006. Etude des propriétés antianémiques de Justicia secunda Vahl (acanthaceae) chez les rats de souche wistar. Pharm Med Trad Afr 14: 45-54. parenchyma. This observation was consistent with that made with the water of Cocos nucifera which lowered uraemia and creatinine in a model of nephropathy induced by ethylene glycol (Gandhi et al, 2013). The same observation was made with crude aqueous extract of the roots of Cocos nucifera or with its ethyl acetate fraction (Tchogou et al., 2017 ; Sènou et al., 2017). The immune status assessed by the number of blood leukocytes was also not modified in the acute and subchronic oral toxicity tests. Histology of the spleen, a peripheral immune organ, also did not show an activated parenchyma, suggesting no immunity disturbance. In fact, an anti-inflammatory activity was observed in animal experiments with the ethyl acetate extract of Cocos nucifera fiber following a local induction of inflammation with xylene (Silva et al, 2009). The results were consistent with those of the crude aqueous extract of Cocos nucifera roots or its ethyl acetate fraction (Tchogou et al., 2017 ; Sènou et al., 2017). Since butanol isolates mainly anthocyanins (Manjusha et al., 2013 ; Koudoro et al, 2014) and the absence of toxicity is known for some members of this family (Pourrat et al., 1967; Taylor, 2015) prospects were opening for the use of plants, which contain them in traditional medicine.

Evans $\mathrm{P}$, Halliwell $\mathrm{B}, \quad 2001$. Micronutrients: oxidant/antioxidant status. $\mathrm{Br} \mathrm{J}$ Nutr. 85(2): S67-S74.

Gandhi M., Aggarwal M, Puri S, Singla SK, 2013. Prophylactic effect of coconut water (Cocos nucifera L.) on ethylene glycol induced nephrocalcinosis in male wistar rat. Int Braz J Urol. 39: 108-117.

Harries HC, 1978. The evolution, dissemination and classification of Cocos nucifera L. The Botanical Rev. 44: 265-319.

Koudoro YA, Dedomè LSO, Yovo M, Agbangnan-Dossa CP, Tchobo PF, Alitonou GA, Avlessi F, Sohounhloué DCK, 2014. Chemical characterization, antiradical and antibacterial activities of extracts of the root bark of Cochlospermum planchoni of Benin. International Journal of Innovation and Applied Studies 7(4): 1582-1594.

Manjusha S, Abrar Hussain M, Manik S, Mohhd YM, Sumeerah Q, Mohd I M and Yogesh C, 2013. Phytochemical Screening and in-vitro Antioxidant Activity Isolated Bioactive Compounds from Tridax procumbens Linn. 
Pakistan Journal of Biological Sciences 16 (24): 1971-1977.

Mapanga RF, Musabayane CT, 2010.The renal effects of blood glucose-lowering plant-derived extracts in diabetes mellitus - an overview. Renal Failure 32: 132-138.

Nasri $H$, Shirzad $H, 2013$. Toxicity and safety of medicinal plants, Journal of Herb. Med. Pharmacol 2(2): 21-22.

OECD, 2002. Guidelines for the Testing of Chemicals, Section 4. Test No. 423: Acute Oral toxicity Acute Toxic Class Method Pages: 14 ISBN: $9789264071001 \quad$ (PDF) DOl: 10.1787/9789264071001

Oduola T, Popoola GB, Avwioro OG, Oduola TA, Ademosun AA, Lawal MO, 2007. Use of Jatropha gossypifolia stem latex as a haemostatic agent: how safe is it? J. Med.Plants Res. 1(1), 014-017.

Okigbo RN, Eme UE, Ogbogu S, 2008. Biodiversity and conservation of medicinal and aromatic plants in Africa. Biotechnol. Mol. Biol. Rev. 3(6): 127134.

Philomena G, 2011. Concerns regarding the safety and toxicity of medicinal plants - An overview. J Appl. Pharmaceut. Sci. 01(6), 40-44.

Pingali PS, Srinivasi P, Reddy MB, 2015. Study of AntiAnemic Effect of Schrebera swietenioides Roxb. in rat models. Asian Journal of Pharmaceutical and Clinical Research 8(5):260-263.

Pourrat $H$, Bastide $P$, Dorier $P$, Tronche $P$, 1967. Preparation and therapeutic activity of some anthocyanin glycosides. Chim Ther 2 :33-8.

Schmincke KH, 2003. Medicinal Plants for forest conservation and healthcare. Non- Wood Forest Products 11, Food and Agriculture Organization of the United Nations.

Senou M, Costa MJ, Massart C, Timmesch M, Khalifa C, Poncin S, Boucquey M, Gérard AC, Audinot JN, Dessy C, Ruf J, Feron O, Devuyst O, Guiot Y, Dumont JE,

Van Sand J, Many MC, 2009. Role of caveolin-1 in thyroid phenotype, cell homeostasis, and hormone synthesis: in vivo study of caveolin-1 knockout mice. Am J Physiol Endocrinol Metab 297: E438-E451.

Sènou M, Tchogou AP, Dougnon TV, Agossadou A, Assogba $F$, Kinsiclounon EG,Koudokpon $H$, Fah L, Fanou B, Akpovi DC, Gbénou J, Lalèyè
A, Loko F, 2016. Efficiency of Sorghum bicolor extract in the treatment of induced anaemia on Wistar rats. International Journal of Biosciences 8 (4): 62-71.

Sènou M, Tchogou AP, Dougnon TV, Agbangnan Dossa CP, Ogue P, Agossadou A, Laleye A, Loko F, Agbonon F, Sezan A, Baba-Moussa L 2017. Safety of ethyl acetate fraction of Cocos nucifera root extract. International Journal of Advanced Research 5(11): 1083-1090

Silva, LCR, Nunes-Pinheiro DCS, Morais SM, LopesNeto BE, Santos GJ, 2009. Avaliac,ão toxicologicale efeito do extratoacetato de etila da fibra de Cocos nucifera L. (Palmae) sobre a respostainflamatória in vivo. Rev Bras Plantas Med 11, 429.

Taylor C W, 2015. Anthocyanins. Adv Nutr. 6(5): 620 622.

Tchogou, A.P, Sènou M, Dougnon TV, Agossadou A, Assogba F, Kinsiclounon EG, Ewedjè $E$, Agbangnan-Dossa CP, Gbénou J, Lalèyè A, Loko F, 2016. The Aqueous Extract of Cocos nucifera L. (Arecaceae) Effectively Treat Induced Anemia. Experimental study on Wistar Rats. International Journal of Biology 8(3) : 554.

Tchogou, AP, Sènou $M$, Agbangnan-Dossa $C P$, Agossadou A, Assogba F, Dougnon TV, Klotoé JR, Gbénou J, Sèzan A, Lalèyè $A$, Loko $F$, 2017. Test of the safety of Cocos nucifera $L$. (Arecaceae) root aqueous extract. Journal of Chemical, Biological and Physical Sciences 7(1) : 282-291.

Verma A, Gupta AK, Kumar A, Khan PK, 2012. Cytogenetic toxicity of Aloe vera (a medicinal Plant). Drug and Chemical Toxicology 35(1): 32-25.

Yakubu MT, Oladiji AT, Akanji MA, 2009. Mode of cellular toxicity of aqueous extract of Fadogia agresti (Schweinf. Ex Hiern) stem in male rat liver and kidney. Human Exp. Toxicol, 28(8) : 469-478. 